\title{
EFFECTS OF MILDEW ON VEGETABLE-TANNED STRAP LEATHER
}

By Joseph R. Kanagy, Arbelia M. Charles, Edward Abrams, and Rees F. Tener

\section{ABSTRACT}

Samples of vegetable-tanned strap leather were exposed to conditions favorable for mildew growth in a tropical room at Fort Belvoir, Va., and in soil burial beds and in a humidity cabinet at the National Bureau of Standards. Mildew under these conditions varied from moderate to very heavy growth.

Physical tests showed that the growth of mildew on leather increased its stiffness, caused a loss in tensile strength, decreased stretch at the breaking point, and weakened the grain surface. Chemical tests revealed a loss of grease, water solubles, glucose, tannins, and nontannins.

No appreciable deterioration of the hide substance was indicated by the tests. The change in physical properties appeared to be due to the mildew activity impairing principally the outer surface of the leather.

The molds in assimilating the grease bring about decomposition (decarboxylation) of the fatty acids. This is shown by a decrease in the saponification number.

Samples of leather containing a fungicidal oil having as active ingredients a mixture of paranitrophenol and pentachlorophenol in equal proportions and aged under the same conditions as the untreated leathers showed no evidence of mildew after 12 weeks.

\section{CONTENTS}

I. Introduction

II. Experimental procedure

1. Selection and sampling of leathers

2. Preparation of samples for exposure tests . . .

3. Conditions of exposure tests_._.

(a) Soil burial

(b) Tropical room_......... 445

(c) Humidity cabinet

4. Laboratory methods_._.

(a) Preparation of specimens for testing

(b) Chemical analyses

(c) Physical tests

III. Results _.

1. Observation of exposed leathers

(a) Soil burial

(b) Tropical room 447

2. Chemical analyses

3. Physical tests

(a) Tensile strength

(b) Stretch at breaking point

(c) Change in stiffness

(d) Flexural fatigue....... 451

IV. General discussion.

V. Summary _... 


\section{INTRODUCTION}

Mildew growth on leather is a very common occurrence in the tropics, and accordingly the war in the South Pacific has created an unusual interest in this subject. Several fungicidal formulas for the prevention of the growth of mildew on leather have been developed by the National Bureau of Standards at the request of the Office of the Quartermaster General. This work has suggested a study of the actual damaging effects of these microorganisms on the leather other than those of changes in appearance and psychological effects on the observer.

A survey of the literature ${ }^{1}$ disclosed studies of the stains produced on hides and leathers and a number of observations on the growth of mildew on leather-making materials. No data to show the effects of mildew on the physical and chemical properties of leather were found.

This report gives the results of an investigation on the effect of mildew on the physical and chemical properties of vegetable-tanned strap leather. The study was made on leathers exposed under controlled conditions varying from mild to severe, when judged on the basis of the rate of growth of mildew.

\section{EXPERIMENTAL PROCEDURE}

\section{SELECTION AND SAMPLING OF THE LEATHERS}

Seven vegetable-tanned strap-leather backs were selected for this work. Six of these were used for experiments in soil burial and in the tropical storage room. The other back was used to ascertain results in the humidity cabinet.
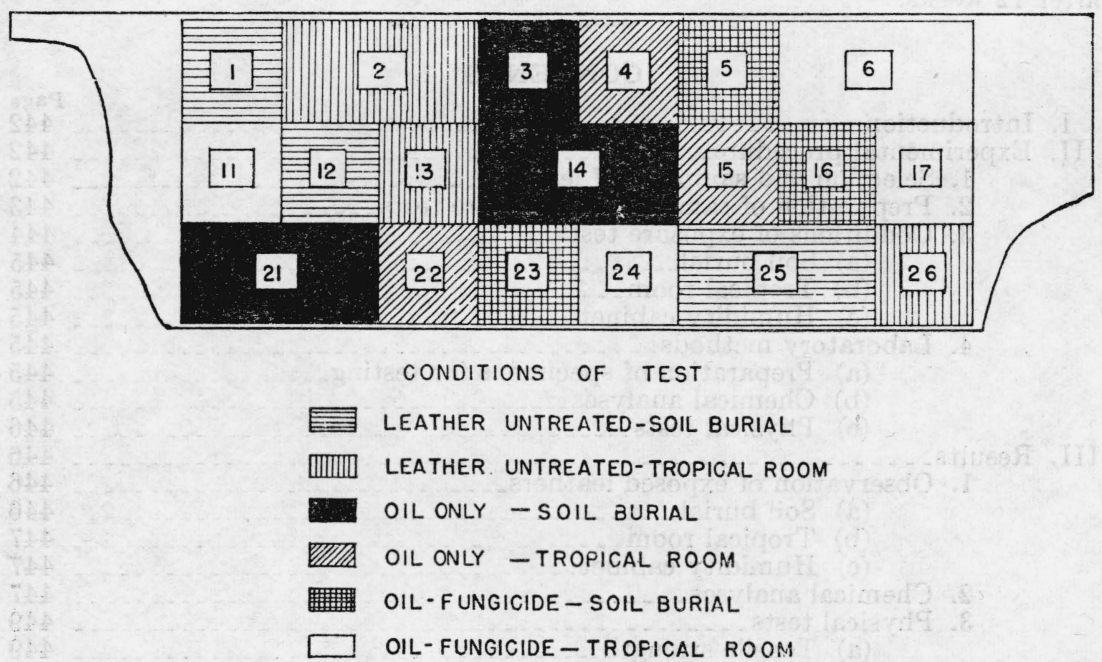

FigURE 1.-Method of sampling vegetable-tanned strap-leather backs for tests in soil burial and tropical room.

Numbers 7 to 10 , Inclusive, and 18 to 20 , inclusive, are omitted.

i J. Int. Soc. Leather Trades Chem. 9, 274 and 355 (1925); 18, 233 (1934); 19, 153 (1935).
J. Am Leather Chem. Assn. 24, 657 (1929). 


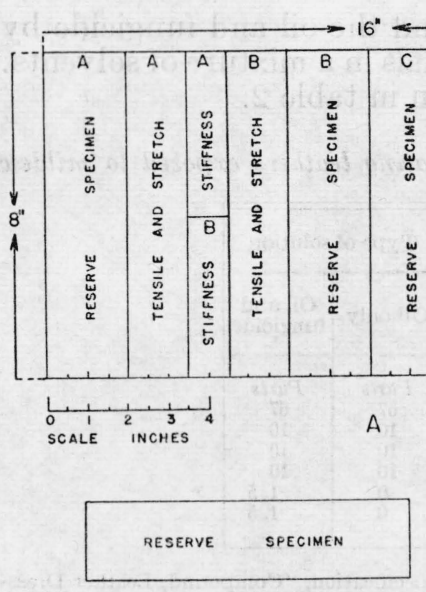

C

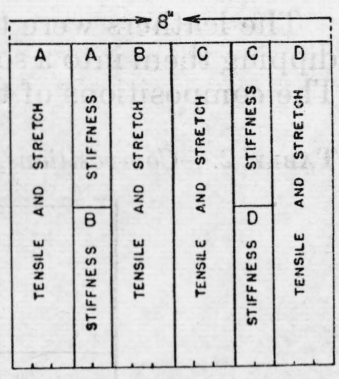

B

Figure 2.-Method of cutting the pieces from the leather samples for the tests.

$A$, Large sample; $B$, small sample; $C$, reserve specimen; $D$, piece exposed to mildew-growing conditions and from which specimens for tensile strength and stretch at break and stiffness determinations were cut.

Six different tests were made with the six backs. The backs were cut so as to obtain uniform sampling for each of the tests. The method adopted for sampling is illustrated in figure 1. The sample series for each test was rotated for each hide, so that each test contained samples from every location shown in figure 1.

The samples measured 16 by 8 inches and 8 by 8 inches. The method of dividing the samples is shown in figure 2. Four sets of pieces were cut from each sample. ${ }^{2}$ One set was used as a control; the others for exposure to mildew.

The back used for the tests in the humidity cabinet was divided into 24 samples 8 by 8 inches. These were separated into two sets by alternate selection for two different tests. Each sample was cut into four sets of pieces, as described above.

\section{PREPARATION OF SAMPLES FOR EXPOSURETTESTS}

Information concerning treatment and exposure conditions for samples cut from the six backs of vegetable-tanned strap leather is given in table 1.

TABLE 1.-Leather treatments and exposure conditions

\begin{tabular}{|c|c|c|}
\hline Test No. & Leather treatment & $\begin{array}{l}\text { Exposure } \\
\text { condition }\end{array}$ \\
\hline 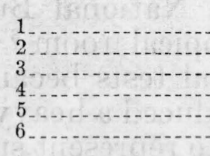 & $\begin{array}{l}\text { Untreated } \\
\text { do } \\
\text { Oil only } \\
\text { oil and fungicide. }\end{array}$ & $\begin{array}{l}\text { Soil burial. } \\
\text { Tropical room. } \\
\text { Soil burial. } \\
\text { Tropical room. } \\
\text { Soil burial. } \\
\text { Tropical room. }\end{array}$ \\
\hline
\end{tabular}

${ }^{2}$ No results are given in this paper for tests on the reserve specimens. The specimens are being held for future reference. 
The leathers were treated with the oil and the oil and fungicide by dipping them into a solution of these materials in a mixture of solvents. The compositions of these solutions is given in table 2 .

TABLE 2.-Compositions of solutions used in treating leathers exposed to mildew

\begin{tabular}{|c|c|c|}
\hline \multirow{2}{*}{ Material 1} & \multicolumn{2}{|c|}{ Type of solution } \\
\hline & Oil only & $\begin{array}{l}\text { Oil and } \\
\text { fungicide }\end{array}$ \\
\hline $\begin{array}{l}\text { Perchloroethylene } \\
\text { Mineral oil } \\
\text { Neatsfoot oil } \\
\text { Cyclohexanone } \\
\text { Paranitrophenol. } \\
\text { Pentachlorophenol }\end{array}$ & $\begin{array}{c}\text { Parts } \\
67 \\
10 \\
10 \\
10 \\
0 \\
0\end{array}$ & $\begin{array}{l}\text { Parts } \\
67 \\
10 \\
10 \\
10 \\
1.5 \\
1.5\end{array}$ \\
\hline
\end{tabular}

1 Materials conform to requirements in Quartermaster Corps Specification, "Compound, Leather Dressng, Preservative, for field treatment."

The two tests in the humidity cabinet were made with leathers dipped in the oil preparation and of other leathers dipped in the oil with fungicide preparation. The amounts of oil added to the leathers varied from 6.5 to 7.0 percent, whereas the total of the two fungicides varied from 0.85 to 0.90 percent. Unpublished data show that this fungicidal formula is effective for at least 30 days with as little as 0.2 percent of the fungicides in the leather. This material has been used for the treatment of shoes and other leather goods at a concentration of approximately 0.5 percent with no evidence of toxicity. It is, however, not recommended for use where direct contact is made with the skin.

The pieces of leather being treated were allowed to dry in a room (having uncontrolled weather conditions) until most of the solvent had evaporated. They were then placed in a conditioning room at $70^{\circ} \mathrm{F}$ and 65-percent relative humidity for 96 hours to allow the remainder of the solvent to evaporate and permit the establishment of equilibrium with the controlled atmosphere. Equilibrium was assumed when the weights of the pieces did not change more than 0.3 percent on two successive weighings 24 hours apart. The final weight was recorded for the determination of the amounts of oil and fungicide absorbed. One piece from each sample was selected for control, whereas the others were used in the exposure tests. These leather samples were exposed for periods of 4,8 , and 12 weeks under each of the conditions described in the following section.

\section{CONDITIONS OF EXPOSURE TESTS}

The conditions of soil burial as used at the National Bureau of Standards for the testing of textiles and a tropical room ${ }^{3}$ at Fort Belvoir, Va., were selected for making the initial tests because from experience it was known that these conditions induced a heavy growth of mildew. The humidity cabinet was selected to represent surroundings where the growth of mildew was only moderate.

3 T. F. Cooke and R. E. Vicklund, Ind. Eng. Chem. Anal. Ed. 18, 59 (1946). 
(a) SOIL BURIAL

In these tests the pieces were imbedded in the soil in a vertical position to the extent of about two-thirds of their length.

A topsoil, known as Chester loam, having a $\mathrm{pH}$ of 5.0 was used. The optimum moisture content for this soil for the growth of microorganisms is considered to be 70 percent of its moisure equivalent. The moisture equivalent of a soil is its water retention capacity under a force of 1,000 times gravity. Seventy percent of the moisture equivalent of this sample of Chester loam has been found to be equal to 25 percent moisture on an oven-dry basis. This moisture content was maintained throughout the period of exposure. The soil bed was enclosed in a tight cabinet, and the temperature of the surrounding atmosphere was maintained at $85^{\circ}$ to $90^{\circ} \mathrm{F}$ and at a relative humidity of approximately 95 percent.

\section{(b) TROPICAL ROOM}

The tropical storage room was operated on the following cycle: For 18 hours each day, the temperature was held at $85^{\circ} \mathrm{F}$ and the relative humidity at 90 percent. During the remaining 6 hours, the temperature was lowered to $75^{\circ} \mathrm{F}$, and the humidity was raised to 95 to 100 percent. Condensation occurred on the leather samples during the 6-hour period. The leather was suspended, by means of wire, from a glass rod supported on a shelf at the sides of the room.

\section{(c) HUMIDITY CABINET}

This cabinet was maintained at $85^{\circ}$ and $90^{\circ} \mathrm{F}$ and at a relative humidity of approximately 95 percent. The pieces were held by means of glass thread tied to a wooden rod that was placed in the uppermost of the cabinet.

\section{LABORATORY METHODS}

(a) PREPARATION OF SPECIMENS FOR TESTING

When the pieces of leather were removed from the different exposure conditions, they were dried under uncontrolled conditions. Mildew and soil were removed by rubbing the leather with a dry scrubbing brush. The pieces were then conditioned at $70^{\circ} \mathrm{F}$ and 65-percent relative humidity. After equilibrium was reached, as determined by maintenance of constant weight for 24 hours, specimens for tensile strength, stretch at the breaking point, and determinations of stiffness were cut from the exposed pieces of leather.

\section{(b) CHEMICAL ANALYSES}

The tensile-strength specimens, after being broken, were ground in a Wiley mill, thoroughly mixed, and used in making the chemical investigation.

This included a complete chemical analysis by the methods described in the Federal Specification KK-L-311, for Leather and Leather Products; General Specifications (Methods of Sampling, Inspection, and Tests). In addition, determinations of iodine and saponification 
numbers were made on the greases, ${ }^{4}$ and estimations of ammonia and soluble nitrogen were made on the leather to determine if any breakdown of the protein occurred.

The saponification number was determined by method 321.2 in Federal Specification KK-L-311. The iodine number was determined by the Wijs method (Methods of Analysis of the Association of Official Agricultural Chemists). Ammonia was determined by extracting $5 \mathrm{~g}$ of the leather with $200 \mathrm{ml}$ of a solution of hydrochloric acid $(0.05 \mathrm{~N})$ by shaking the mixture in a bottle for 4 hours. One hundred milliliters of the filtered extract was placed in a Kjeldahl flask, sufficient magnesium oxide was added to make the solution alkaline, and the extracted ammonia was determined by distilling it into standardized acid.

Soluble nitrogenous materials were determined by extracting $2 \mathrm{~g}$ of the leather in $200 \mathrm{ml}$ of sodium carbonate solution $(0.1 \mathrm{~N})$ by shaking the mixture in a bottle for 4 hours. The extract was filtered and the total nitrogen was determined on a $100 \mathrm{ml}$ portion of the filtrate by method 350.1 in Federal Specification KK-L-311.

\section{(c) PHYSICAL TESTS}

Determinations of tensile strength and stretch at the breaking point were made in accordance with method 240.1 in Federal Specification $\mathrm{KK}-\mathrm{L}-311$.

Stiffness was determined in accordance with method 250.1 in the same specification. The relative stiffness factor was calculated for an angle of 20 degrees and a span of 2 inches.

Specimens previously used in the stiffness measurements were employed for the flexural fatigue tests. The fatigue machine was the one described by M. Maeser. ${ }^{5}$ In order to accelerate the test, the method was modified however, by drilling a hole $(3 / 16$ inch) in the middle of the cross section where the specimen is notched. The end point was recorded when a crack was formed all the way across one of the two sections formed by the drilled hole and the notches.

\section{RESULTS}

\section{OBSERVATION OF EXPOSED LEATHERS}

(a) SOIL BURIAL

Within 2 days after exposure a heavy white mycelium was noticed on the exposed portion of the oil-treated leather. By the end of the first week this had developed into a uniform black coating of Aspergillus niger, and at the end of the first 4 weeks a very heavy coating of this mold was present. No other organism manifested itself at this time. At the end of the second and third exposure periods, the exposed portions of the oil-treated specimens showed luxuriant growths of Aspergillus niger, with an overgrowth of an olive green Penicillium.

The specimens that contained no added oil showed a slight growth of Aspergillus niger; but in this case various species of Penicillium were also present, along with a strain of Aspergillus oryzae. At the end

4 Includes added oils and original stuffing mixture.

s J. Am. Leather Chem. Assn. 39, 35 (1944). 
of 12 weeks of exposure, an increased amount of growth of a variety of organisms was evident, but the underlying surface of the leather was still partly visible.

The portions of the specimens treated with fungicide that were exposed above ground showed no evidence of growth even after 12 weeks of exposure.

The buried portions of these specimens showed little or no growth. However, a few colored spots which are believed to have been of bacterial origin were noticed on the buried portions of all pieces, including those treated with fungicide.

\section{(b) TROPICAL ROOM}

The types of mold on the specimens in the tropical room were similar to those on the portions of the samples that were above ground in the soil-burial tests. The molds were also more abundant in the tropical room than in the burial tests, but there was no evidence of spots similar to those on the buried portions in the soil-burial tests.

The samples treated with the fungicides showed no evidence of growth at any time. There were droplets collected at the bottom of the specimens, however, and there was some evidence of spue on the surface of those having the highest precentage of water-soluble materials.

\section{(c) HUMIDITY CABINET}

Mildew-growth on the leather under the conditions of the humidity cabinet was only of moderate extent. The grain side of the leather was almost completely covered with a moderate growth of Aspergillus niger, whereas the flesh surface was sparsely covered with a slight growth of this mold.

\section{CHEMICAL ANALYSES}

In table 3 are given analyses of the composite samples used in the soil-burial and tropical-room tests, together with the results of tests applied to the greases and the determinations of soluble nitrogen compounds. Also included are similar analyses after the various exposure periods; and, in addition, the analytical results of similar tests applied to leathers exposed in the humidity cabinet.

Differences due to exposure conditions rather than to the effect of mildew are reflected in the results of the chemical analyses. The leathers exposed to soil burial showed increases in ash and $\mathrm{pH}$ value. The ash increase is undoubtedly caused by pickup from the soil since, as shown, the ash contained calcium and magnesium salts.

The leathers exposed to the tropical room absorbed ammonia from an accidentally contaminated atmosphere. This resulted in an increase in $\mathrm{pH}$ and in the hydrolysis of some of the tanning material, as shown by the increase in water solubles and tannins.

The leathers not treated with fungicides showed a large decrease in percentage of grease. Samples containing fungicide showed small grease losses, which may be attributed to adsorption of grease by the soil for the soil-burial samples, and possibly to leaching for the tropical-room and humidity-cabinet samples.

Leathers treated with fungicides and exposed in the humidity cabinet showed considerable losses in water-soluble materials.

$689974-46-4$ 
TABLE 3.-Chemical analyses of leather used in mildew study

\begin{tabular}{|c|c|c|c|c|c|c|c|c|c|c|c|c|c|c|c|c|c|c|}
\hline Conditions of tests & $\begin{array}{l}\text { Time } \\
\text { of ex- } \\
\text { posure }\end{array}$ & $\begin{array}{l}\text { Mois- } \\
\text { ture }\end{array}$ & $\mathrm{pH}$ & Ash & $\begin{array}{c}\text { Grease, } \\
\text { hide- } \\
\text { sub- } \\
\text { stance } \\
\text { basis }\end{array}$ & Grease & $\begin{array}{l}\text { Hide } \\
\text { sub- } \\
\text { stance }\end{array}$ & $\begin{array}{c}\text { Water } \\
\text { sol- } \\
\text { ubles }\end{array}$ & $\begin{array}{l}\text { Degree } \\
\text { of tan- } \\
\text { nage }\end{array}$ & $\begin{array}{l}\text { Non- } \\
\text { tan- } \\
\text { nins }\end{array}$ & $\begin{array}{l}\text { Tan- } \\
\text { nins }\end{array}$ & $\begin{array}{l}\text { Glu- } \\
\text { cose }\end{array}$ & $\begin{array}{c}\text { Magne- } \\
\text { sium } \\
\text { sulfate } 1\end{array}$ & $\begin{array}{l}\text { Cal- } \\
\text { cium } \\
\text { oxide }\end{array}$ & $\begin{array}{c}\text { Iodine } \\
\text { num- } \\
\text { ber }\end{array}$ & $\begin{array}{l}\text { Sapon- } \\
\text { ifica- } \\
\text { tion } \\
\text { num- } \\
\text { ber }\end{array}$ & $\begin{array}{c}\text { Nitro- } \\
\text { gen 2 } \\
\text { extrac- } \\
\text { tion } \\
\text { with } \\
\text { HCl } \\
\text { solu- } \\
\text { tion }\end{array}$ & $\begin{array}{c}\mathrm{Nitro}^{-} \\
\text {gen }{ }^{3} \\
\text { extrac- } \\
\text { tion } \\
\text { with } \\
\mathrm{Na}_{2} \mathrm{CO}_{3} \\
\text { solu- } \\
\text { tion }\end{array}$ \\
\hline $\begin{array}{l}\text { Leather untreated; soil } \\
\text { burial }\end{array}$ & $\left\{\begin{array}{r}\text { Weeks } \\
0 \\
4 \\
8 \\
12\end{array}\right.$ & $\begin{array}{r}\text { Percent } \\
13.2 \\
13.3 \\
15.6 \\
15.6\end{array}$ & $\begin{array}{l}3.4 \\
3.6 \\
3.6 \\
3.9\end{array}$ & $\begin{array}{r}\text { Percent } \\
0.67 \\
1.18 \\
1.16 \\
1.39\end{array}$ & $\begin{array}{r}\text { Percent } \\
12.8 \\
8.3 \\
6.5 \\
5.3\end{array}$ & $\begin{array}{r}\text { Percent } \\
6.4 \\
4.0 \\
3.3 \\
2.8\end{array}$ & $\begin{array}{c}\text { Percent } \\
50.4 \\
51.7 \\
51.6 \\
52.8\end{array}$ & $\begin{array}{r}\text { Percent } \\
11.2 \\
8.4 \\
7.7 \\
7.2\end{array}$ & $\begin{array}{l}63 \\
69 \\
72 \\
70\end{array}$ & $\begin{array}{r}\text { Percent } \\
3.4 \\
3.0 \\
3.0 \\
3.0\end{array}$ & \begin{tabular}{|r|} 
Percent \\
7.8 \\
5.4 \\
4.7 \\
4.2
\end{tabular} & $\begin{array}{r}\text { Percent } \\
0.78 \\
.40 \\
.58 \\
\text { Trace }\end{array}$ & $\begin{array}{r}\text { Percent } \\
0.65 \\
.60 \\
.87 \\
1.06\end{array}$ & $\begin{array}{r}\text { Percent } \\
\text { Trace } \\
0.26 \\
.28 \\
.27\end{array}$ & $\begin{array}{l}54 \\
73 \\
70 \\
71\end{array}$ & $\begin{array}{r}186 \\
163 \\
83 \\
113\end{array}$ & $\begin{array}{r}\text { Percent } \\
0.06 \\
.08 \\
.03 \\
.05\end{array}$ & $\begin{array}{r}\text { Percent } \\
0.20 \\
.24 \\
.26 \\
.30\end{array}$ \\
\hline $\begin{array}{l}\text { Leather untreated; trop- } \\
\text { ical room }\end{array}$ & $\begin{array}{r}0 \\
4 \\
8 \\
12\end{array}$ & $\begin{array}{l}13.2 \\
14.6 \\
18.4 \\
17.7\end{array}$ & $\begin{array}{l}3.4 \\
5.9 \\
6.3 \\
6.3\end{array}$ & $\begin{array}{l}0.67 \\
.59 \\
.59 \\
.57\end{array}$ & $\begin{array}{r}12.8 \\
7.9 \\
5.0 \\
4.3\end{array}$ & $\begin{array}{l}6.4 \\
4.3 \\
2.9 \\
2.5\end{array}$ & & $\begin{array}{r}11.2 \\
17.0 \\
14.8 \\
8.8\end{array}$ & $\begin{array}{l}63 \\
43 \\
42 \\
50\end{array}$ & $\begin{array}{l}3.4 \\
4.1 \\
4.3 \\
2.7\end{array}$ & $\begin{array}{r}7.8 \\
12.9 \\
10.5 \\
6.1\end{array}$ & $\begin{array}{r}0.78 \\
.30 \\
\text { Trace } \\
\text { Trace }\end{array}$ & $\begin{array}{r}0.65 \\
.65 \\
.65 \\
.65\end{array}$ & & $\begin{array}{l}54 \\
69 \\
68 \\
72\end{array}$ & $\begin{array}{r}186 \\
175 \\
99 \\
111\end{array}$ & $\begin{array}{l}.06 \\
.51 \\
.70 \\
.71\end{array}$ & $\begin{array}{l}.20 \\
.82 \\
.86 \\
.85\end{array}$ \\
\hline Oil only; soil buria & $\begin{array}{r}0 \\
4 \\
8 \\
12\end{array}$ & $\begin{array}{l}12.3 \\
13.0 \\
15.7 \\
15.6\end{array}$ & $\begin{array}{l}3.4 \\
3.7 \\
3.8 \\
4.0\end{array}$ & $\begin{array}{r}.58 \\
.94 \\
1.16 \\
1.33\end{array}$ & & $\begin{array}{r}13.4 \\
8.1 \\
6.9 \\
6.5\end{array}$ & & $\begin{array}{r}10.6 \\
8.6 \\
7.7 \\
7.3\end{array}$ & $\begin{array}{l}64 \\
63 \\
61 \\
60\end{array}$ & $\begin{array}{l}3.0 \\
2.8 \\
2.5 \\
2.9\end{array}$ & $\begin{array}{l}7.6 \\
5.8 \\
5.2 \\
4.4\end{array}$ & $\begin{array}{l}0.94 \\
.68 \\
.48 \\
.12\end{array}$ & $\begin{array}{r}.49 \\
.26 \\
.85 \\
1.34\end{array}$ & $\begin{array}{r}\text { Trace } \\
0.18 \\
.27 \\
.31\end{array}$ & $\begin{array}{l}61 \\
61 \\
55 \\
50\end{array}$ & $\begin{array}{r}147 \\
97 \\
67 \\
55\end{array}$ & $\begin{array}{l}.05 \\
.10 \\
.03 \\
.05\end{array}$ & $\begin{array}{l}.09 \\
.31 \\
.23 \\
.32\end{array}$ \\
\hline Oil only; tropical room & $\begin{array}{r}0 \\
4 \\
8 \\
12\end{array}$ & $\begin{array}{l}12.2 \\
13.9 \\
18.1 \\
17.7\end{array}$ & $\begin{array}{l}3.4 \\
5.9 \\
6.2 \\
6.3\end{array}$ & $\begin{array}{r}0.63 \\
.60 \\
.51 \\
.56\end{array}$ & $\begin{array}{l}27.9 \\
19.9 \\
15.4 \\
10.8\end{array}$ & $\begin{array}{r}12.9 \\
10.3 \\
8.5 \\
6.2\end{array}$ & & $\begin{array}{l}10.9 \\
16.9 \\
14.6 \\
11.1\end{array}$ & $\begin{array}{l}65 \\
40 \\
39 \\
44\end{array}$ & $\begin{array}{l}3.1 \\
4.0 \\
4.0 \\
3.0\end{array}$ & $\begin{array}{r}7.8 \\
12.9 \\
10.6 \\
8.1\end{array}$ & $\begin{array}{r}1.08 \\
0.64 \\
.48 \\
.12\end{array}$ & $\begin{array}{l}0.44 \\
.44 \\
.44 \\
.44\end{array}$ & & $\begin{array}{l}61 \\
59 \\
58 \\
53\end{array}$ & $\begin{array}{r}144 \\
113 \\
92 \\
60\end{array}$ & $\begin{array}{l}.05 \\
.50 \\
.60 \\
.66\end{array}$ & $\begin{array}{l}.04 \\
.81 \\
.84 \\
.81\end{array}$ \\
\hline $\begin{array}{l}\text { Oil and fungicide; soil } \\
\text { burial }\end{array}$ & $\begin{array}{r}0 \\
4 \\
8 \\
12\end{array}$ & $\begin{array}{l}10.2 \\
11.9 \\
14.1 \\
14.9\end{array}$ & $\begin{array}{l}3.5 \\
3.3 \\
3.5 \\
3.7\end{array}$ & $\begin{array}{r}.58 \\
.81 \\
1.06 \\
1.25\end{array}$ & & & & $\begin{array}{r}10.3 \\
7.6 \\
6.6 \\
5.7\end{array}$ & $\begin{array}{l}63 \\
65 \\
65 \\
66\end{array}$ & & $\begin{array}{l}7.3 \\
5.7 \\
4.7 \\
3.3\end{array}$ & $\begin{array}{l}.76 \\
.76 \\
.20 \\
.14\end{array}$ & $\begin{array}{r}.41 \\
.41 \\
.57 \\
1.47\end{array}$ & $\begin{array}{r}\text { Trace } \\
0.20 \\
.33 \\
.34\end{array}$ & $\begin{array}{l}59 \\
66 \\
66 \\
63\end{array}$ & $\begin{array}{l}141 \\
139 \\
121 \\
114\end{array}$ & $\begin{array}{l}.06 \\
.09 \\
.03 \\
.05\end{array}$ & $\begin{array}{l}.17 \\
.25 \\
.25 \\
.33\end{array}$ \\
\hline $\begin{array}{l}\text { Oil and fungicide; trop- } \\
\text { ical room }\end{array}$ & $\begin{array}{r}0 \\
4 \\
8 \\
12\end{array}$ & $\begin{array}{l}11.9 \\
12.8 \\
16.2 \\
15.4\end{array}$ & $\begin{array}{l}3.5 \\
6.0 \\
6.2 \\
6.2\end{array}$ & $\begin{array}{r}0.57 \\
.49 \\
.47 \\
.45\end{array}$ & $\begin{array}{l}29.0 \\
30.6 \\
30.1 \\
26.9\end{array}$ & $\begin{array}{l}13.5 \\
14.9 \\
15.4 \\
14.1\end{array}$ & & $\begin{array}{l}10.4 \\
16.5 \\
16.2 \\
14.1\end{array}$ & $\begin{array}{l}63 \\
41 \\
35 \\
37\end{array}$ & $\begin{array}{l}3.0 \\
4.3 \\
4.1 \\
3.3\end{array}$ & $\begin{array}{r}7.4 \\
12.2 \\
12.1 \\
10.8\end{array}$ & $\begin{array}{l}.80 \\
.42 \\
.46 \\
.08\end{array}$ & $\begin{array}{r}0.43 \\
.43 \\
.52 \\
.43\end{array}$ & & $\begin{array}{l}63 \\
71 \\
67 \\
64\end{array}$ & $\begin{array}{l}142 \\
150 \\
123 \\
131\end{array}$ & $\begin{array}{l}.04 \\
.49 \\
.60 \\
.63\end{array}$ & $\begin{array}{l}.24 \\
.69 \\
.75 \\
.84\end{array}$ \\
\hline $\begin{array}{l}\text { Oil only; humidity } \\
\text { cabinet. }\end{array}$ & $\begin{array}{r}0 \\
4 \\
8 \\
12\end{array}$ & $\begin{array}{l}13.4 \\
13.1 \\
15.0 \\
15.9\end{array}$ & $\begin{array}{l}\text { 3. } 2 \\
3.1 \\
3.1 \\
3.2\end{array}$ & $\begin{array}{l}2.48 \\
1.54 \\
1.66 \\
1.34\end{array}$ & $\begin{array}{l}40.7 \\
36.6 \\
33.6 \\
29.7\end{array}$ & $\begin{array}{l}14.8 \\
14.0 \\
12.4 \\
12.4\end{array}$ & $\begin{array}{l}36.3 \\
38.2 \\
40.0 \\
41.7\end{array}$ & $\begin{array}{l}16.4 \\
12.8 \\
12.6 \\
10.8\end{array}$ & $\begin{array}{l}89 \\
91 \\
87 \\
84\end{array}$ & $\begin{array}{l}7.5 \\
4.0 \\
4.7 \\
3.4\end{array}$ & $\begin{array}{l}8.9 \\
8.8 \\
7.9 \\
7.4\end{array}$ & $\begin{array}{r}1.96 \\
0.04 \\
\text { Trace } \\
0.08\end{array}$ & $\begin{array}{l}2.41 \\
2.06 \\
2.21 \\
1.38\end{array}$ & $\begin{array}{l}0.04 \\
.04 \\
.05 \\
.05\end{array}$ & $\begin{array}{r}96 \\
94 \\
100 \\
96\end{array}$ & $\begin{array}{r}102 \\
107 \\
80 \\
66\end{array}$ & $\begin{array}{l}0.05 \\
.04 \\
.02 \\
.03\end{array}$ & $\begin{array}{l}0.24 \\
.23 \\
.24 \\
.24\end{array}$ \\
\hline $\begin{array}{l}\text { Oil"and fungicide; hu- } \\
\text { midity cabinet }\end{array}$ & $\begin{array}{r}0 \\
4 \\
8 \\
12\end{array}$ & $\begin{array}{l}13.0 \\
13.9 \\
14.3 \\
14.6\end{array}$ & $\begin{array}{l}\text { 3. } 3 \\
3.3 \\
3.3 \\
3.4\end{array}$ & $\begin{array}{l}2.25 \\
1.23 \\
1.03 \\
0.75\end{array}$ & $\begin{array}{l}43.8 \\
39.7 \\
37.3 \\
35.6\end{array}$ & $\begin{array}{l}15.5 \\
15.1 \\
15.2 \\
14.8\end{array}$ & $\begin{array}{l}35.3 \\
38.0 \\
40.6 \\
41.5\end{array}$ & $\begin{array}{r}17.8 \\
12.7 \\
10.6 \\
9.0\end{array}$ & $\begin{array}{l}89 \\
90 \\
83 \\
83\end{array}$ & $\begin{array}{l}8.3 \\
4.5 \\
3.5 \\
2.2\end{array}$ & $\begin{array}{l}9.5 \\
8.2 \\
7.1 \\
6.8\end{array}$ & $\begin{array}{l}2.28 \\
1.94 \\
0.92 \\
.50\end{array}$ & $\begin{array}{l}3.24 \\
1.27 \\
1.37 \\
0.70\end{array}$ & $\begin{array}{l}.04 \\
.04 \\
.05 \\
.05\end{array}$ & $\begin{array}{l}92 \\
92 \\
94 \\
91\end{array}$ & $\begin{array}{l}116 \\
121 \\
105 \\
113\end{array}$ & $\begin{array}{l}.05 \\
.04 \\
.05 \\
.03\end{array}$ & $\begin{array}{l}.24 \\
.25 \\
.23 \\
.23\end{array}$ \\
\hline
\end{tabular}




\section{PHYSICAL TESTS}

(a) TENSILE STRENGTH

The results of tensile-strength tests are given in figure 3. Mildewed leathers (not treated with fungicides) showed greater losses in tensile strength than those treated with fungicides. After the first 4 weeks, the samples exposed to soil burial and in the humidity cabinet lost tensile strength at a lower rate than those exposed in the tropical room.

The buried fungicide-treated leathers developed greater losses in tensile strength for the 12 -week period than similar specimens exposed in either the tropical room or the humidity cabinet for the

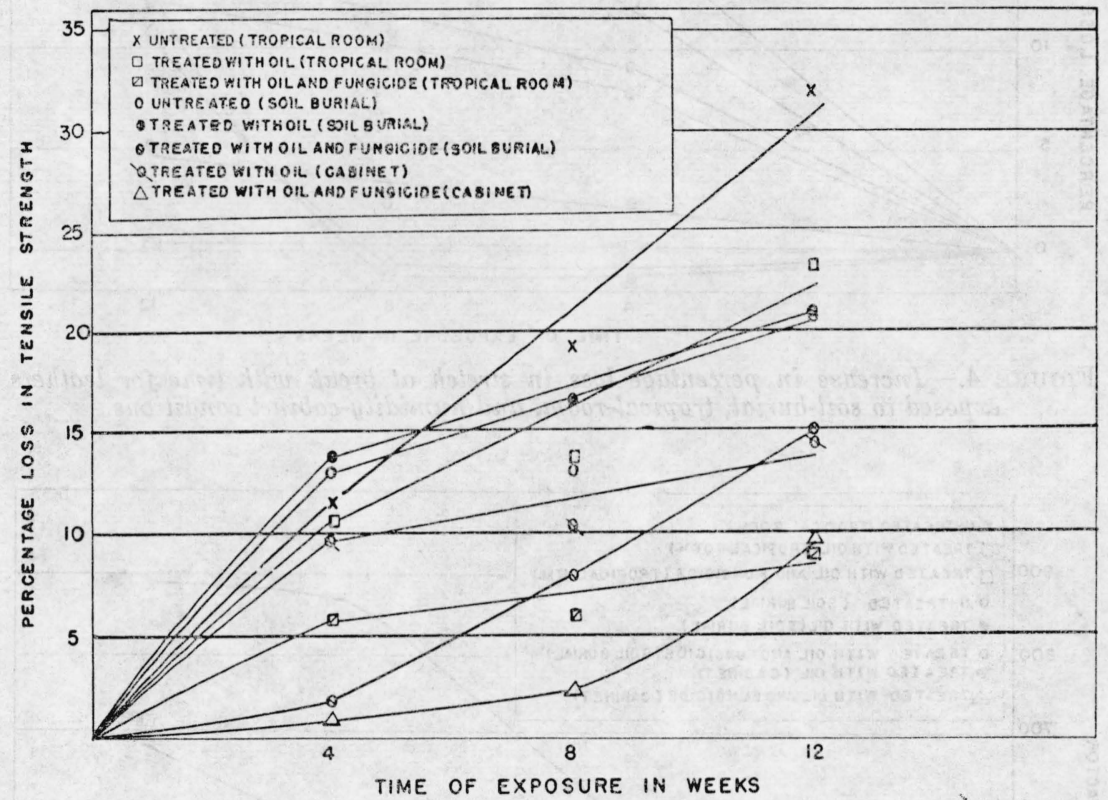

FIGURE 3.-Increase in percentage loss in tensile strength with time for leathers exposed to soil-burial, tropical-room, and humidity-cabinet conditions.

same time period. This may have been the result of conditions in the soil.

\section{(b) STRETCH AT BREAKING POINT}

The percentage loss in stretch at the breaking point (fig. 4) correlates well with the results of the tensile-strength tests (fig. 3), with the exception of the humidity-cabinet tests. These showed no appreciable change in loss of stretch before the 12-week exposure period.

(c) CHANGE IN STIFFNESS

The results of the stiffness measurements are plotted in figure 5 . All the curves cut the ordinate at a relative stiffness-factor value of 190 , since this was the average result for all the control specimens. 


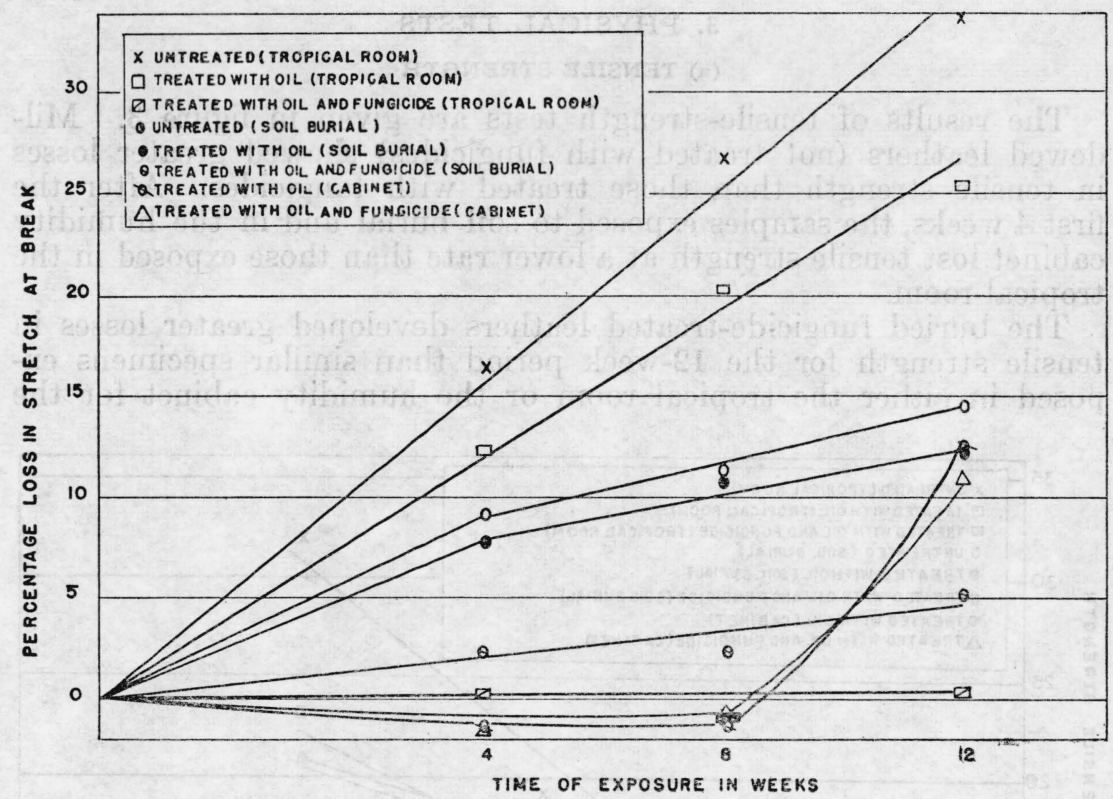

Figure 4.-Increase in percentage loss in stretch at break with time for leathers exposed to soil-burial, tropical-room, and humidity-cabinet conditions.

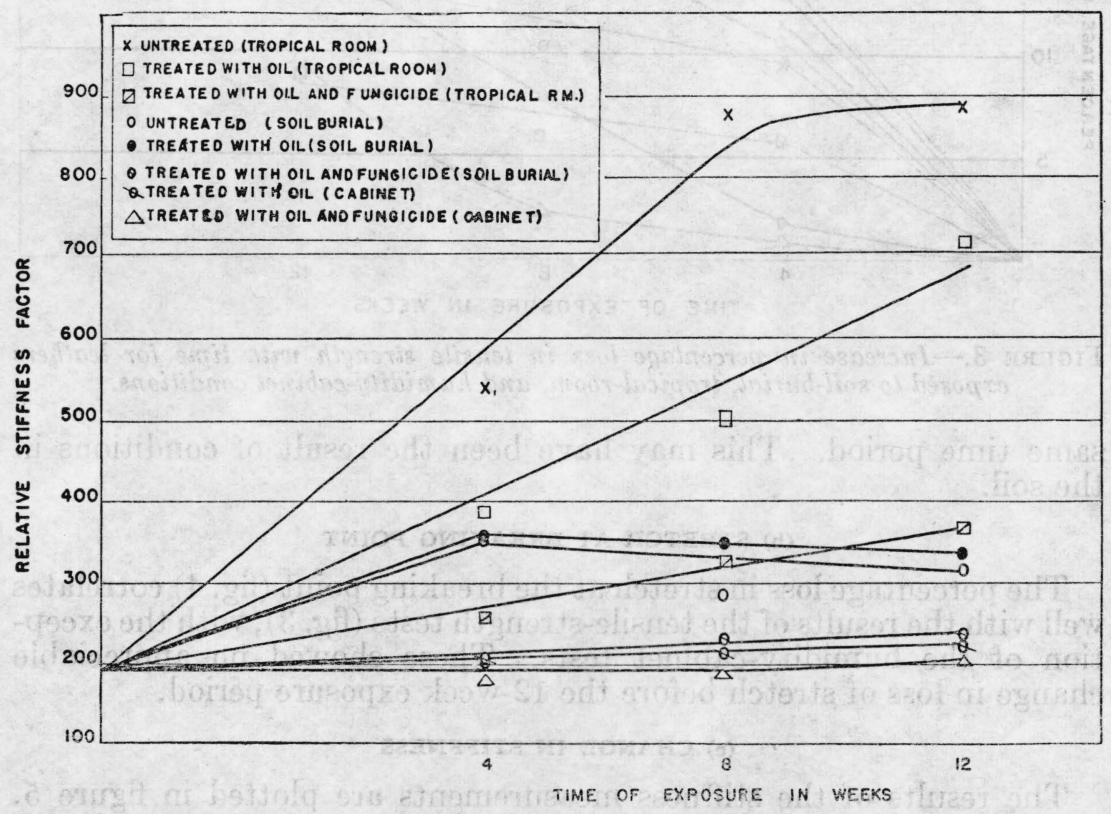

FIGURE 5.-Increase in relative stiffness factor with time for leathers exposed to soil-burial, tropical-room, and humidity-cabinet conditions. 
All the leathers that had a growth of mildew showed greater increases in stiffiness than the exposed specimens treated with fungicides and had no growth of mildew. The samples exposed to soil burial showed decreasing stiffness values after the first 4 weeks of exposure. This may have been caused by the slow redistribution of grease from the interior to the surfaces of the leather. The surface of the leather had probably lost a considerable amount of grease during the first 4 weeks of underground storage because of close contact with the surrounding soil. After the first 4 weeks, the loss to the soil was less, and a redistribution of grease then took place in the leather.

Stiffness specimens were cut from portions of the soil-burial specimens that were either completely covered with soil or only partly submerged. This may be visualized from the diagram of the piece shown in figure $2, D$. The stiffness specimen was exposed above or below the soil, depending upon which end of the piece was placed in the soil.

In table 4 are given the results" of changes in the relative stiffness factor of specimens exposed above and of those exposed beneath the soil.

TABLE 4.-Comparative change in relative stiffness factor ${ }^{1}$ of specimens from soil burial tests exposed above and below the soil

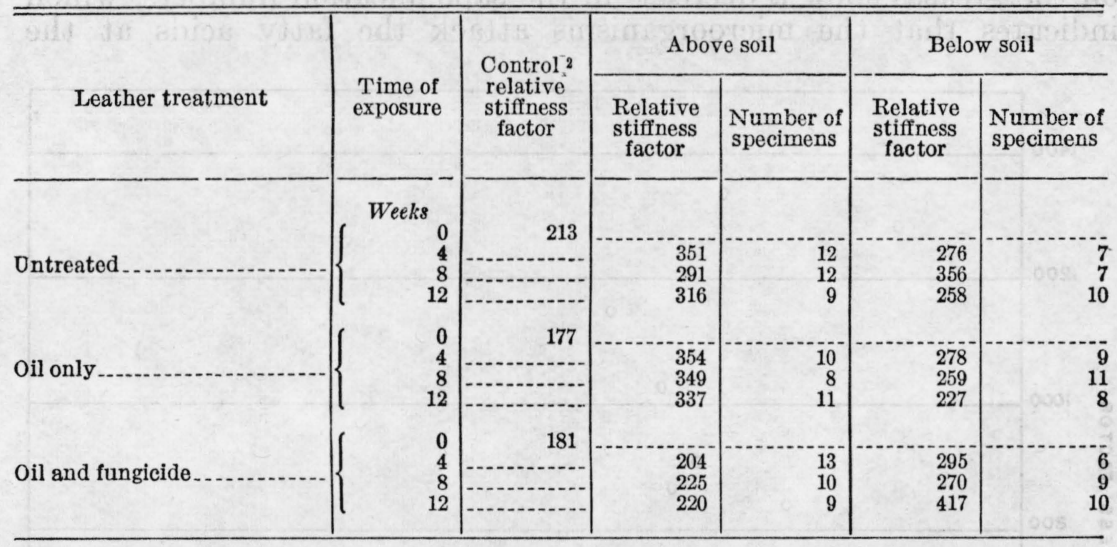

1 Calculated at angle of 20 degrees and span ef 2 inches.

A verage of 19 specimens.

These data show that leathers with mildew gradually increased in stiffness when aged above ground. Leathers without mildew increased in stiffness when exposed below the soil. These findings indicate that contact with soil increases the stiffness of leather, as might be expected. In this respect, however, mildew appears to be more effective than soil action.

(d) FLEXURAL FATIGUE

The results of flexural-fatigue tests for the leathers aged in the humidity cabinet are given in table 5. They show that there is considerably more tendency for the grain to crack on those that had supported mildew than on those that had no mildew growth. 
TABLE 5.-Resistance of leathers, exposed to mildew-growing conditions in humidity cabinet, to flexural fatigue in the Maeser machine

\begin{tabular}{|c|c|c|c|}
\hline 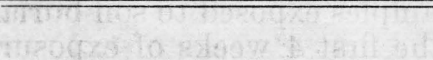 & $+2 x^{2}$ & \multicolumn{2}{|c|}{ Grain crack 1} \\
\hline Leather treatment & $\begin{array}{l}\text { Time of } \\
\text { exposure }\end{array}$ & Started & $\begin{array}{l}\text { Across } \\
\text { specimen }\end{array}$ \\
\hline Treated withoil only & $\left\{\begin{array}{r}\text { Weeks } \\
8 \\
8 \\
12 \\
12 \\
12\end{array}\right.$ & $\begin{array}{r}\text { Flexes } \\
28,080 \\
21,360 \\
15,740 \\
16,200 \\
15,310\end{array}$ & $\begin{array}{c}\text { Flexes } \\
241,570 \\
31,800 \\
27,240 \\
29,520 \\
20,300\end{array}$ \\
\hline Treated with oil and fungicide....... & $\left\{\begin{array}{l}12 \\
12 \\
12\end{array}\right.$ & $\begin{array}{l}\text { (3) } \\
34,080 \\
33,890\end{array}$ & $\begin{array}{l}\quad(3) \\
241,570 \\
36,860\end{array}$ \\
\hline
\end{tabular}

Machine runs through oycle having 41,570 flexes. Specimens were tested through only 1 cycle. Not completely across.

No crack in first cycle.

\section{GENERAL DISCUSSION}

The results of the tests give evidence that the growth of mildew on leather is supported by the greases, which act as a nutrient. Tests on the greases show a decrease in the saponification numbers, which indicates that the microorganisms attack the fatty acids at the

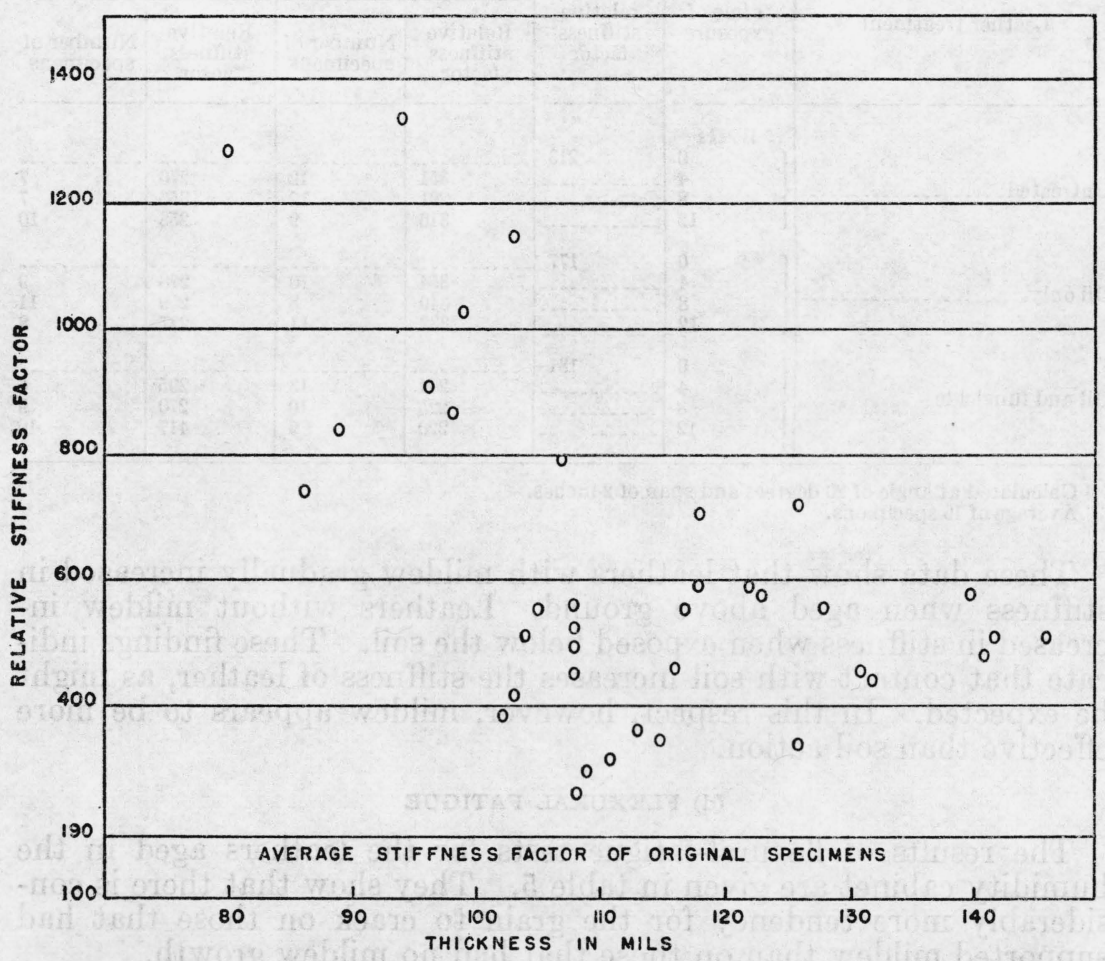

FIGURE 6.-Variation of relative stiffness factor with thickness of the specimens. 
carboxyl group and decarboxylation apparently occurs. Iodinenumber determinations give a possible indication of dehydrogeneration of fatty oils and the preferential assimilation of them. This is shown by an increase in iodine number where only fatty oils are present and a decrease in iodine numbers where mineral oil is also present.

It is not definitely proved by these results that the mildew assimilates the tannins. The leathers not treated with a fungicide and exposed to the tropical-room tests show larger decreases in tanning materials than those that were treated and did not support mildew growth, but apparently an indeterminable amount of this loss was caused by leaching.

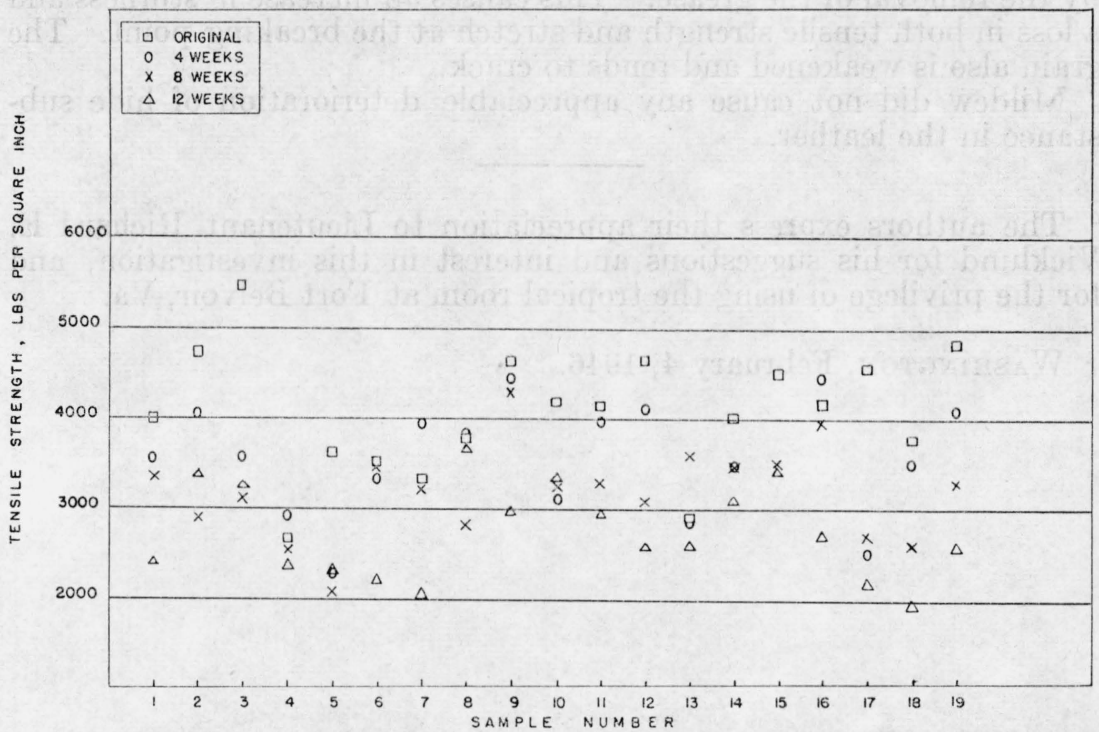

Frgure 7.-Tensile strengths of individual specimens of untreated leather exposed in the tropical room for 4,8 , and 12 weeks.

As the growth of mildew occurs on the outer surface of the leather, it would be expected that the effect of the mildew would be most severe on the thinner leathers, which have the highest percentage of outer surface per unit weight. In figure 6 the relative stiffness factors of the specimens not treated with the fungicides and aged in the tropical room for 12 weeks are plotted against their thicknesses. The original specimens had relative stiffness factors varying from 70 to 380 , with an average of 190 . These results show that the thinner leathers have the greatest increases in stiffness.

Tests of the soluble nitrogenous materials in the exposed leathers, as determined by extracting with $0.1-N$ sodium carbonate solution, show that no appreciable deterioration of the hide substance has occurred. In figure 7 are shown the percentage losses in tensile strength of each specimen of leather that had been given no treatment and exposed to the tropical room. Only one of these speci- 
mens has a final tensile strength of less than 2,000 pounds, even though the control specimen of some of these samples was not appreciably higher. This indicates further that no breakdown of the basic chemical structure of the hide substance has occurred and that the loss in tensile strength is principally caused by changes in the physical structure of the leather. The maintenance of chemical stability should prevent, as indicated, the reduction of tensile strength below some definite minimum value.

\section{SUMMARY}

The action of mildew on vegetable-tanned leather produces changes in its physical properties. These changes are caused, at least in part, by the removal of the grease. This causes an increase in stiffness and a loss in both tensile strength and stretch at the breaking point. The grain also is weakened and tends to crack.

Mildew did not cause any appreciable deterioration of hide substance in the leather.

The authors express their appreciation to Lieutenant Richard E. Vicklund for his suggestions and interest in this investigation, and for the privilege of using the tropical room at Fort Belvoir, Va.

Washington, February 4, 1946. 